\title{
Students' intuitive and analytical thinking in the mathematics study through the integration of STAD and environmental islamic jurisprudence (fiqh)
}

\author{
Abdillah', Ajeng Gelora Mastuti', Muhammad Rijal'1, Muhajir Abd. \\ Rahman' \\ ${ }^{1}$ IAIN Ambon, Indonesia \\ 四abdillah@iainambon.ac.id *
}

\author{
Article Information \\ Submitted March 28, 2020 \\ Revised April 15, 2020 \\ Accepted April 24, 2020
}

\section{Keywords}

Analytical Thinking;

Cooperative STAD;

Environmental Awareness; Intuitive

\begin{abstract}
The success of a learning process depends on the teacher's mastery of materials, strategies, and media. Teachers need to possess high creativity to maintain their students' interest and motivation in learning. The integration of effective learning models and appropriate media, such as using plastic waste as realia, can be one of the alternatives to improve the quality of learning. This study also aimed to examine students' awareness of environmental issues. The quantitative and qualitative data of the study were collected simultaneously to answer the research problems. Interviews were conducted during the implementation of the learning process and quizzes. A pre-experimental one-shot case study design was employed to gather the quantitative data which were then analyzed descriptively. The results of the current study showed that the students' intuitive thinking started to develop in phase 3 , where they were asked to identify the type of plastic glass they were holding. Phase 4 that allowed the students to separate parts constructing the glass, determine the name of each part, and set a point of view or the purpose underlying the material presented was the phase where the students performed an analytical thinking process. In phase 5, the students were allowed to solve a mathematical problem using analytical thinking. The interaction between students' intuitive and analytical thinking shown in the identification and labeling of each type of three-dimensional form will be discussed in this article
\end{abstract}

\section{INTRODUCTION}

Plastic waste is a major cause of environmental pollution. Around 52.2\% of irrigation is predominantly polluted by plastic waste (Sulaeman et al., 2018). Plastic waste is carcinogenic to humans. It can lead to birth defects, immune disorders, endocrine disorders, and reproductive disorders (Pavani \& Rajeswari, 2014). In dealing with plastic waste problems, the current study attempted to explain the use of plastic waste as a learning medium to help students understand the concept of three-dimensional shapes with curves. Besides that, the importance of understanding environmental Fiqh for students to realize environmental sustainability is also very necessary (Jamaluddin, 2018; Noor, 2018; Zuhdi, 2015). So, this article also outlines the potential role of university students as the members of an intellectual community who can be involved in plastic waste management. Concerning this, the understanding of plastic waste management needs to be integrated into mathematics learning at the university.

The integration of the Student Team Achievement Division (STAD) and Islamic Jurisprudence (Fiqh) of the Environment has been implemented in "School Mathematics Development" courses (Ardiyani et al, 2018; Purwanti \& Musadat, 2018). However, the results

$\begin{array}{ll}\text { 'How to cite } & \text { Abdillah, A., Mastuti, A. G., Rijal, M., \& Rahman, M. A. (2020). Students' intuitive and analytical thinking in the } \\ & \text { mathematics study through the integration of STAD and environmental islamic jurisprudence (fiqh). Al-Jabar: } \\ & \text { Jurnal Pendidikan Matematika, 11(1), 49-60. } \\ \text { E-ISSN } & 2540-7562 \\ \text { Published by } & \text { Mathematics Education Department, UIN Raden Intan Lampung. }\end{array}$


thinking through STAD and Environmental Fiqh. Therefore, the current study aimed to investigate how university students performed intuitive and analytical thinking through the integration of Student Team Achievement Division (STAD) and Islamic Jurisprudence (Fiqh) of the Environment as well as examine how plastic waste was utilized as a learning medium in the process.

Research has shown the importance of intuitive and analytical thinking in problemsolving (Kurniawati et al., 2014; Nurhanurawati et al., 2018; Okoli \& Watt, 2018; Panbanlame et al, 2014). Kurniawati (2014) argue that intuitive thinking is necessary for students in solving mathematical problems, especially in predicting the correct answers to the problems and exploring the problems by identifying mathematical concepts or formulas involved in them, using various strategies, or giving various examples of statements on certain mathematical concepts. Nurhanurawati (2018) state that there might be some accuracy issues raised when studying the convergence of sequences in Real Analysis. To reduce the problems, students must be allowed to use their intuitive thinking as a decisive part of acquiring new knowledge. In other words, student intuition is highly required in the first step to solving a problem (Panbanlame et al., 2014).

\section{METHODS}

A concurrent mixed methods design was employed in this study. A mixed-methods design is a procedure for collecting and analyzing data by bringing together quantitative and qualitative methods in a series of analyses to understand the research problems. In concurrent studies, especially, quantitative and qualitative data are collected simultaneously and combined to answer the research problems (Creswell, 2013). The current concurrent study aimed to explore university students' intuitive and analytical thinking through the implementation of the integrated Student Team Achievement Division (STAD) and Environmental Islamic Jurisprudence (Fiqh) learning model. This study also aimed to describe the students' environmental awareness during the implementation of the learning model. The total participants in this study were 124 students. They consisted of four classes of four-semester students from the Department of Mathematics Education of IAIN Ambon and UIN Alauddin Makassar.

The quantitative data of this study were obtained by conducting a pre-experimental study with a one-shot case study design without control classes. These data were analyzed using quantitative descriptive analysis. The participants were given a special treatment in the form of learning using the integration of STAD and environmental Fiqh for a month. Concurrently, qualitative observations and interviews were conducted to investigate major phenomena occurring during the learning process. The students' intuitive and analytical thinking was explored at every stage of learning using the integration of STAD and environmental Fiqh, meanwhile, the quantitative data of the study, in the form of students' environmental awareness, were collected at the fifth phase (evaluation phase) of learning using a questionnaire. 


\section{RESULTS AND DISCUSSION}

The findings of this study depict the results of the development and implementation of a learning model, namely the Integrated Student Team Achievement Division (STAD) and Islamic Jurisprudence (Fiqh) of the environment. The syntax of the learning model can be seen in Table 1:

Tabel 1. The Syntax of the Integrated STAD and Environmental Fiqh Learning Mode

\begin{tabular}{ll}
\hline \multicolumn{1}{c}{ Phase } & \multicolumn{1}{c}{ Activity } \\
\hline $\begin{array}{l}\text { Phase-1: Group } \\
\text { Arrangement }\end{array}$ & $\begin{array}{l}\text { The lecturer/researcher helps the students form a study } \\
\text { group and assists each of the groups in transitioning } \\
\text { efficiently } \\
\text { The lecturer/researcher delivers the objectives of learning } \\
\text { Phase-2: Delivery of the } \\
\text { learning objectives and } \\
\text { motivational speech }\end{array}$ \\
$\begin{array}{l}\text { invites the students to go outside the classroom to collect } \\
\text { plastic waste, and motivates them to study } \\
\text { The lecturer/researcher presents information by using a used } \\
\text { phase-3: Presentation of } \\
\text { phformation }\end{array}$ & $\begin{array}{l}\text { The lecturer/researcher guides the study groups to complete } \\
\text { their task } \\
\text { group study assistance } \\
\text { Phase-5: Evaluation or } \\
\text { assessment }\end{array}$ \\
$\begin{array}{l}\text { The lecturer/researcher holds quizzes to evaluate the } \\
\text { students' learning outcomes and distributes a questionnaire } \\
\text { to examine the students' environmental awareness } \\
\text { Fase-6: Award grants }\end{array}$ & $\begin{array}{l}\text { The lecturer/researcher gives an award to an individual or a } \\
\text { group for their hard work during the learning process }\end{array}$ \\
\hline
\end{tabular}

\section{Phase-1}

In phase 1, the students were organized into heterogeneous study groups based on their ability levels. Group arrangement is a part of the STAD learning syntax that particularly aims to develop students' cooperative skills.

\section{Phase-2}

In phase-2, the researcher delivered the objectives of learning using the Integrated STAD and Environmental Fiqh learning model. The researcher invited all the students to work together with the lecturer and observer outside the classroom for ten minutes. Each of the students was asked to collect plastic garbage and bring it to the classroom. The most dominant type of plastic waste found by the students around the campus environment was drinking glasses made of plastic. The plastic waste found by each student was collected in a study group that was previously formed in phase 1 . The researcher then encouraged the students to learn by using a plastic glass as realia. The researcher also emphasized the concept of tubes and cones and increased the students' environmental awareness through the use of plastic glass as a learning medium.

\section{Phase-3}

Data on the students' intuitive and analytical thinking in phase- 3 were obtained through direct interactions between the researcher and the students in an investigative activity to understand the concept of tube and cone sections. Information was presented by asking each group to observe a plastic glass that had been collected in the previous phase. A plastic glass was raised in front of the students as an example while asking the students about the name or type of the three-dimensional shape they were holding. 
The following figure contains an illustrated model of the three-dimensional shape of a used plastic glass:

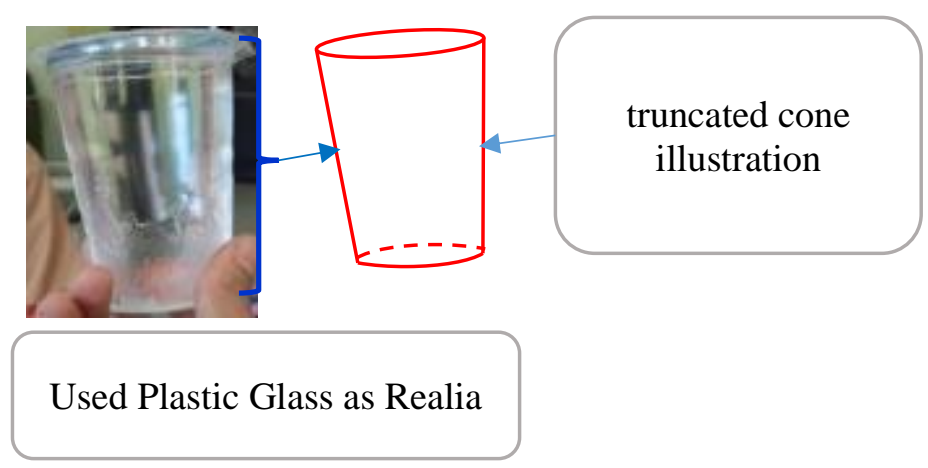

Figure 1. Used Plastic Glass as Realia and Truncated Cone Illustration

The participants from the four classes provided a relatively similar pattern for answering the researcher's question. They spontaneously said that the glass was a tube in shape. The following excerpt shows an example of the students' answer to the question:

R: Hey Guys, Please pay attention to the plastic glass you and I hold!

S: Yes, Sir.

$\mathrm{R}$ : What shape is it?

S: A three-dimensional shape, Sir.

R: What kind?

$\mathrm{S}$ : It is a tube, Sir (The students spontaneously answered in unison)

Each of the groups was asked to clarify their answers. The result showed that all of the students agreed that the plastic glass was a tube.

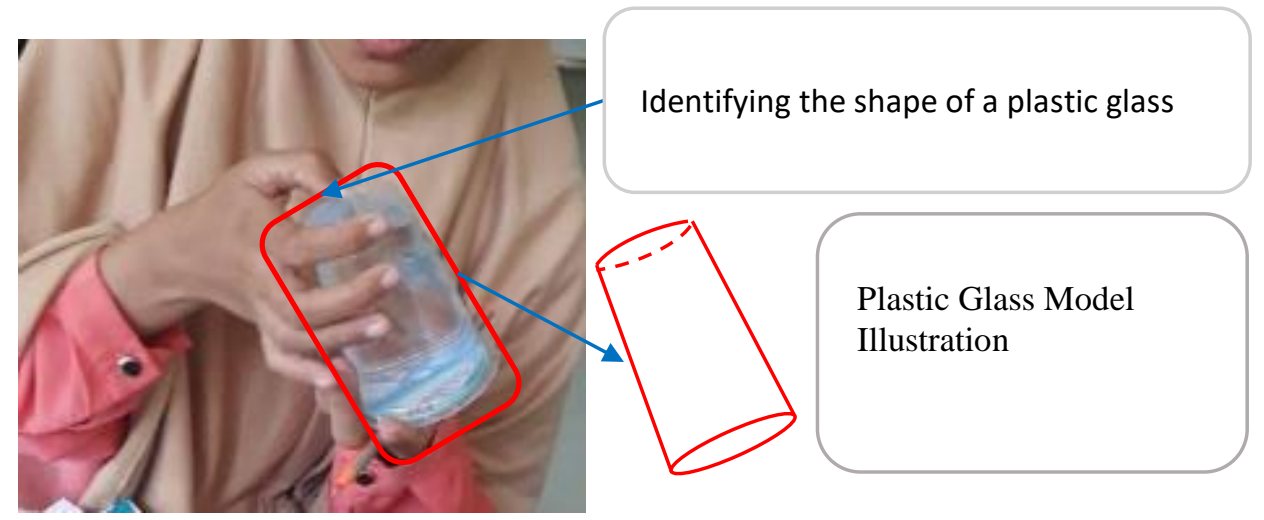

Figure 2. Student Identifying the Shape of a Plastic Glass

The students' spontaneous answer indicated their intuitive thinking. According to Abdillah (2017) spontaneous behaviors that are performed based on feelings are a self-evidence characteristic that can be owned without further justification or verification. The conclusion that the plastic glass was a tube was considered true by itself. The truth of the conclusion was accepted based on feelings and therefore required no further justification of verification. This finding is confirmed by Malewska (2018) who states that intuitive thinking occurs based on the structure of knowledge formed as a result of various types of learning. This process, according to Malewska (2018), takes place when an individual can put his/her knowledge or experiences into action. 
The result of the analysis conducted to each student showed that every individual used intuitive and analytical thinking to construct their understanding of the three-dimensional model. Their intuitive thinking was signified through their spontaneity in answering the researcher's question about the name of the three-dimensional shape. The students' statement mentioning that the plastic glass was a tube was based on their previous experiences or knowledge that the model resembled a tube. Furthermore, the evidence of the students' analytical thinking was found in the way the students distinguished parts that make up the model, determined how these parts fit or function within the structure, and determining points of view or purposes underlying how these shapes are built.

The following section contains a review of the data and a discussion of the students' response patterns during individual investigations. The investigation began with the researcher asking the student about the name or type of three-dimensional shape of the model held by the researcher. The student could quickly answer that "it is a tube" because s/he has had a previous experience where a similar model was claimed as a tube. According to Abdillah et al (2016), using intuitive thinking to solve problems is an alternative to decision making.

Furthermore, the student's analytical thinking was shown in his/her behavior in breaking down and examining each part of the plastic glass model, especially the circular top and bottom part of the glass. The student was able to identify the model's base and circular shaped lid but got a bit confused because the sizes of the base and lid of the model s/he held were different from those demonstrated by the researcher. In line with this, Firdaus et al., (2015) point out that analytical thinking involves activities to test, question, connect and evaluate all aspects of a situation or problem. Besides, Abdillah et al., (2016) state that an analytical thinking process begins with identifying a problem, then breaking it into parts that are going to be analyzed and connected to make a decision. Figure 2 shows the activity of a student when identifying a plastic glass.

Figure 2 demonstrates the effort of a student in identifying elements that construct a plastic glass. The student paid careful attention to the base, top part, and curved surface of the model, but looked confused since the area of the base was different from the area of the top part of the model. Her confusion was shown in the following excerpt.

$\mathrm{S}$ : What is this shape..., it looks like a tube, but... this is different (while pointing at the base) from this (while pointing at the top part of the model).

Besides mentioning that the model was a tube, the student also stated that the model resembled a cylinder. She got confused because according to her, the cylinder was another term for the tube. At last, she expressed her uncertainty in the type of plastic glass used for learning using the Integrated STAD and Environmental Fiqh.

\section{Phase-4}

In phase-4, the researcher explained the concept of a plastic-made three-dimensional shape and its relation to the Islamic view of environmental issues. The researcher began with an explanation that plastic waste that had been collected from the campus environment can be used as a learning medium. Then, the researcher described the Islamic perspective on waste issues. The researcher emphasized the fact that plastic waste that is scattered around the classroom floor and campus environment is very uncomfortable to look at. Therefore, it can be utilized as a learning medium. After that, the researcher read Al-Qur'an surah Ar-Rum:41 (Al-Qur'an, 
2015) and explained the purpose of the verse and reminded the students that trash or used goods can be used as learning media or teaching aids.

The researcher also revealed the words of Prophet Muhammad Saw. that were associated with environmental issues. These words were narrated by At-Tirmidzi (2015), as follows: "For Allah is good and likes the good, Allah is clean and loves cleanliness, Allah is the Giver and loves giving, Allah is the Most Gracious and loves generosity. Thus, clean your yard and your terrace. Don't imitate the Jews". Furthermore, the researcher emphasized his point by quoting (Majelis Ulama Indonesia, 2014) on waste management to prevent environmental damage. The Fatwa states that: (1) Every Muslim is obliged to maintain the cleanliness of the environment, utilize goods for the benefits of others, and avoid oneself from various diseases as well as tabżir and israf deeds; (2) Every Muslim is prohibited from littering and/or disposing of goods that can still be used for themselves or others; (3) The government and entrepreneurs are obliged to manage waste to avoid harm to living things; (4) The government and entrepreneurs are obliged to recycle waste into goods that are useful for improving the welfare of the people.

The final step of learning in this phase was to explain the curved three-dimensional shapes. The researcher helped the students construct their understanding by asking them to pay attention to the parts that make up the plastic glass object. Then, the students were asked to discuss it with their group members and finally communicate the result to the researcher. The construction of geometry concepts with concrete building models is an important part in understanding geometry (Dewi et al, 2018; Imswatama \& Lukman, 2018; Sutiarso et al, 2017) revealed that the investigation of the properties of geometry and concrete shape is an important part in understanding geometry. The results of their research prove that the teaching media can help students understand concepts in geometry. Dewi (2018) found that the use of teaching aids could motivate students in participating in mathematical problem-solving. The application of teaching aids in the classroom can also improve students' mastery of geometrical concepts in mathematics learning. Imswatama \& Lukman (2018) found that during mathematical problemsolving, students were stimulated to formulate concepts on the definitions, characteristics, and circumference of rectangles by experimenting with tools and objects around them. Moreover, Imswatama \& Lukman (2018) concluded that this activity was effective in improving the students' mathematical skills and critical thinking. This is in line with one of the activities of the Integrated STAD and Environmental Fiqh where the students were asked to identify parts of the three-dimensional shape. This exploration activity allowed the students to think intuitively, analytically, and critically.

The next step was to help the students understand that the top and base parts of the plastic glass model was circular in different sizes. The model also had a curved side which was a truncated sector in shape instead of a rectangular. Given this information, it can be concluded that the model was actually not a tube, but a truncated cone, a cone with the tip straight cut off. Figure 3 contains the researcher's illustration of a truncated cone. 


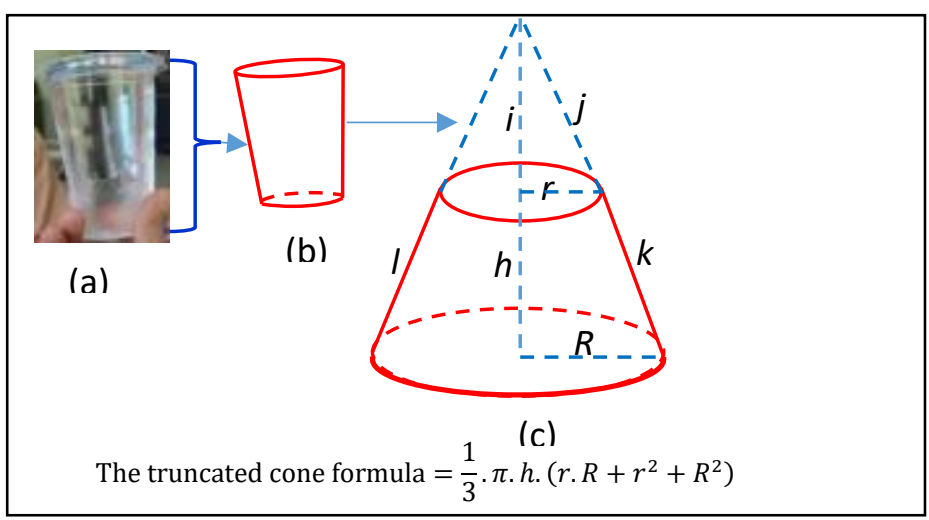

Figure 3. Truncated Cone Illustration

The researcher drew the plastic glass model (a) as shown in Figure 3 (b) on the board, then rotated the model $180^{\circ}$ to obtain Figure 3 (c). Then, the researcher explained to the students that if line $\mathrm{k}$ and line 1 were dragged upward (while demonstrating it), then they would intersect in one point. The researcher's activity is similar to those suggested in Eriana et al., (2019) and Sutiarso et al., (2017) who found that using realia could effectively improve students' concept mastery in mathematics learning.

Soon after Figure 3 (c) has been completely drawn, the researcher invited the students to rediscover the truncated cone formula. The researcher provided scaffolding and guidance for the students on triangle congruence. Scaffolding is a notion that refers to assistance provided by an adult or an expert (a teacher in this case) for the younger or the less knowledgeable ones. Scaffolding involves adults who control the elements of a task that are beyond students' capacity. Scaffolding allows students to concentrate on completing the elements of a task that are within their competency reach (Wood et al, 1976). Scaffolding given by the researcher could help the students discover the following the truncated cone formula:

The truncated cone formula $=\frac{1}{3} \cdot \pi \cdot h \cdot\left(r \cdot R+r^{2}+R^{2}\right)$

This finding is corroborated with those of (Inkeeree et al, 2018; Ling et al, 2016). Ling et al., (2016) revealed that in cooperative learning, students could compete and work together in groups until their enthusiasm and creativity in learning were boosted. Furthermore, Ling et al., (2016) states that cooperative learning in Mathematics leads to better outcomes because the students are put in a relaxed learning environment that encourages them to be more advanced in asking questions as a group. Similarly, Inkeeree et al., (2018) argue that students can work as a team to develop social interaction skills that contribute to better achievement especially in learning mathematics. Scaffolding, according to Sutiarso et al., (2017), can be provided in various ways, such as cards, handouts, instructions, examples, questions, stories, explanations, and visuals. Scaffolding is one of the teacher's strategies to bridge abstract concepts of geometry into the concrete.

\section{Phase-5}

In phase 5, the researcher used a quiz to evaluate the students' environmental awareness and the understanding of geometry concepts. Each student was equipped with a plastic bottle, a plastic ruler, a piece of paper containing a mathematical problem, and a questionnaire consisting of 22 question items. The researcher asked the students to solve the problem (Figure 4) individually. 
Question: "The net content or the volume of the bottle in front of you is $600 \mathrm{ml}$. Determine how to find out the volume of the bottle!"

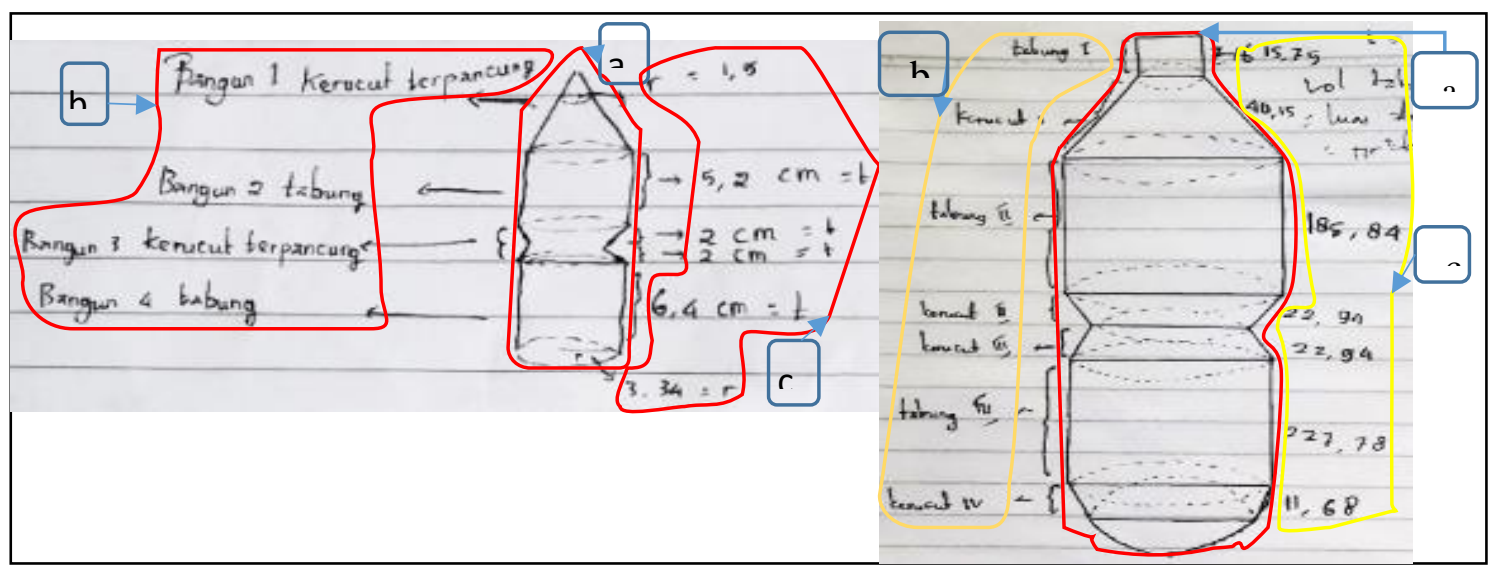

Figure 5. Student Work

An analytical thinking process was demonstrated in Figure 5. Based on the example, it was known that the student (in particular) did the following to determine the formula of the bottle volume. First, the student performed a "differentiating" activity. It was obvious that the student started by distinguishing the types of shapes that make up the bottle (Figure 5 (a) and (b)). Figure 5 (a) represents a bottle with a known volume, while Figure 5 (b) represents the types of shapes that make up the bottle. The second activity that the student did was attributing or assigning names for each shape that makes up the bottle model. As shown in Figure 5 (b), the student labeled each part by mentioning shape 1 as a truncated cone, shape 2 as a tube, shape 3 as a truncated cone, and shape 4 as a tube. Finally, the student's organizing activity was shown in the way the student's arrangement of the shape (shape 1, shape 2, shape 3 , and shape 4). After organizing the order, the student measured the length of each part and wrote down their respective sizes.

Activities conducted by the student are in line with those revealed in (Abdillah, 2017; Maharani, 2014). Maharani (2014) states that students' analytic thinking is characterized by the ability to describe, determine and analyze information used to understand knowledge by reasoning and thinking logically, not merely based on feelings or guesses. Abdillah (2017) argues that differentiating is marked by students' activity in distinguishing relevant and irrelevant parts of an object. Organizing is characterized by determining how an element fits or functions in a structure. Attributing is marked by how the students determine the point of view, bias, values, or intentions that underlie the material presented as well as identify and construct the problem. Labeling an object is usually based on previous experiences; thus, this activity is categorized into an intuitive thinking behavior (Eames, 2014; Järvilehto, 2015). Therefore, a series of activities conducted by the student may suggest that there is an interaction between the student's intuitive and analytical thinking (Abdillah et al., 2016).

According to (Vale \& Barbosa, 2018), the strategy performed by the student in Figure 5 enables him to discover alternative solutions, simplify the process of problem-solving, and at the same time connect knowledge with experiences and develop thinking flexibility, which constitutes one of the characteristics of analytic thinking. Vale \& Barbosa (2018) also states that analytic thinking with visual strategies has the potential to enlighten students that blind manipulation of symbols and procedures is not always possible, but necessary and 
complementary for more formal and complex understanding. The result of the student's calculation of the bottle volume can be seen in Figure 6 as follows:

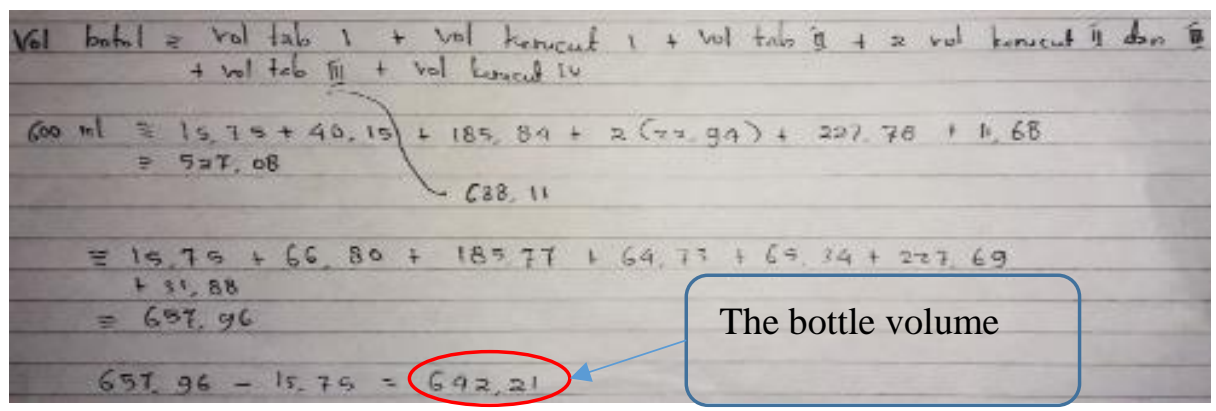

Figure 6. Calculation of the Bottle Volume

Figure 6 shows proof that the student found the bottle volume $(642.21 \mathrm{ml})$ by first calculating the volume of each shape making up the bottle. The activity performed by the student is categorized into an analytical thinking behavior (Abdillah, 2017; Maharani, 2014).

After finishing the task, all of the students were asked to fill in a questionnaire on environmental awareness. The result of the survey showed that $90.48 \%$ of the students provided positive responses to the implementation of the Integrated STAD and Environmental Fiqh in the classroom. Seventy percent of the students had high environmental awareness and $76 \%$ of the students agreed that a clean and healthy campus environment can be realized by the existence of official regulations from the campus. Besides, the result of the Pearson Correlation analysis showed that there was a strong and positive correlation between the learning model implementation and the students' environmental awareness (r, 0.936), also suggesting that the Integrated STAD and Environmental Fiqh could significantly affect the students' environmental awareness (Sig. value (1-tailed) or the probability is $0.000<0.05$ ). This finding corresponds with those by Ling et al., (2016) who discovered that the Student Team Achievement Division (STAD) was effective in encouraging the teacher and the students to be innovative and creative, especially in improving the quality of learning in the classroom. Also, Heidari \& Heidari, (2015) state that the most appropriate method and the best system for enhancing environmental knowledge in society are to provide materials, activities, and structures that help individuals perceive themselves as responsible for protecting the environment. Furthermore, according to Heidari \& Heidari (2015), the teacher must acquire knowledge about environmental issues so that s/he can teach it to the students. It is also important for the teacher to constantly remind the students that environmental education can be provided in the long term or medium term as well as inform the students about their role in protecting the environment.

Activities conducted in phase 2, 3, and 4 are in line with findings from (Karataş \& Karataş, 2016; Valderrama-Hernández et al, 2017) on environmental education. Karataş \& Karataş, (2016) state that environmental education has a purpose to develop a world population who are aware of, care about the environment and the problems associated with it, and have the knowledge, skills, attitudes, motivations, and commitments to work individually and collectively towards solutions to current problems and new prevention methods. Similarly, Valderrama-Hernández et al. (2017) argue that to overcome the complexity of environmental problems, it is necessary to involve teachers in the development of environmental education. 


\section{Phase-6}

In phase-6, an award was granted to the group who could show their best effort in participating. The award given to the exemplary group was in the form of references. This activity is confirmed by the results of the research by (Rahayu et al., 2017; Sari, 2017), stating that appreciation for students will result in improving their motivation in learning because they feel respected when bringing out ideas in their minds. As a result, the students feel that individual efforts and teamwork highly contribute to the success of their groups.

\section{CONCLUSIONS}

The results of the current study showed that the students' intuitive thinking started to develop in phase 3, where they were asked to identify the type of plastic glass they were holding. Phase 4 that allowed the students to separate parts constructing the glass, determine the name of each part, and set a point of view or the purpose underlying the material presented was the phase where the students performed an analytical thinking process. In phase 5, the students were allowed to solve a mathematical problem using analytical thinking. At this stage, the students were able to distinguish the type of each shape constructing a plastic bottle (differentiating), assigning each type with a name (attributing), and labeling the names in order and calculating the length of each part (organizing). These activities were then followed by the interaction between the students' intuitive and analytical thinking that was shown in identifications and labeling of each type of three-dimensional shapes. Furthermore, the students' analytical thinking was also shown in the process of calculating the bottle volume by first identifying each shape constructing the bottle. Besides, the result of the questionnaire on environmental awareness showed that $90.48 \%$ of students provided positive responses towards the implementation of the Integrated STAD and Environmental Fiqh learning model. More than $70 \%$ of the students showed a "strongly agree" or "agree" attitude and over $76 \%$ of students assumed that a clean and healthy campus environment can be realized with the support of the campus through official regulations.

\section{AUTHOR CONTRIBUTIONS STATEMENT}

AA and AGM worked as the main drafter in this study. MR and MAR assists the implementation and design of research articles.

\section{REFERENCES}

Abdillah, A. (2017). Berpikir Intuitif dan Analitik Siswa dalam Menyelesaikan Masalah Matematis "Informasi Terbatas". (Dissertation). Universitas Negeri Malang, Malang.

Abdillah, A., Nusantara, T., Subanji, S., Susanto, H., \& Abadyo, A. (2016). The students decision making in solving discount problem. International Education Studies, 9(7), 5763.

Al-Qur'an. (2015). Al-Qur'an Tajwid dan Terjemah, Departemen Agama RI. Bandung: Diponegoro.

Ardiyani, S. M., Gunarhadi, G., \& Riyadi, R. (2018). Realistic mathematics education in cooperative learning viewed from learning activity. Journal on Mathematics Education, 9(2), 301-310. 
At-Tirmidzi. (2015). Hadits tirmidzi nomor 2723. Retrieved April 12, 2020, from Tafsir AlQuran Online website: https://tafsirq.com/hadits/tirmidzi/2723

Creswell, J. W. (2013). Research design pendekatan kualitatif, kuantitatif, dan mixed. yogyakarta: Pustaka Pelajar.

Dewi, M. L., Hakim, A. R., Setiawan, A., Adhisuwignjo, S., \& Rohadi, E. (2018). Mathematics teaching Aids to improve the students abstraction on geometry in civil engineering of state polytechnic Malang. IOP Conference Series: Materials Science and Engineering, 434, 15.

Eames, C. L. (2014). Investigating children's intuitive and analytical thinking about path length as a developmental phenomenon. Illinois State University.

Eriana, E., Kartono, K., \& Sugianto, S. (2019). Understanding ability of mathematical concepts and students' self-reliance towards learning by implementing manipulative props (APM) on jigsaw technique. Journal of Primary Education, 8(2), 176-183.

Firdaus, F., Kailani, I., Bakar, Md. N. B., \& Bakry, B. (2015). Developing critical thinking skills of students in mathematics learning. Journal of Education and Learning (EduLearn), 9(3), 226-236.

Heidari, F., \& Heidari, M. (2015). Effectiveness of management of environmental education on improving knowledge for environmental protection (case study: Teachers at Tehran's school). International Journal of Environmental Research, 9(4), 1225-1232.

Imswatama, A., \& Lukman, H. S. (2018). The effectiveness of mathematics teaching material based on ethnomathematics. International Journal of Trends in Mathematics Education Research, 1(1), 35-38.

Inkeeree, H. K., Fauzee, M. S., \& Othman, M. K. (2018). The effects of student achievement team-division (STAD) on achievement and retention in mathematics of thai students. European Journal of Education Studies, 5(2), 33-47.

Jamaluddin, J. (2018). Fiqh al-bi'ah ramah lingkungan; Konsep thaharah dan nadhafah membangun budaya bersih. Tribakti: Jurnal Pemikiran Keislaman, 29(2), 324-345.

Järvilehto, L. (2015). The nature and function of intuitive thought and decision making. Springer International Publishing.

Karataş, A., \& Karataş, E. (2016). Environmental education as a solution tool for the prevention of water pollution. Journal of Survey in Fisheries Sciences, 3(1), 61-70.

Kurniawati, L., Kusumah, Y. S., Sumarmo, U., \& Sabandar, J. (2014). Enhancing students' mathematical intuitive-reflective thinking ability through problem-based learning with hypnoteaching method. Journal of Education and Practice, 5(36), 130-135.

Ling, W. N., Ghazali, M. I. B., \& Raman, A. (2016). The effectiveness of student teamsachievement division (STAD) cooperative learning on mathematics achievement among school students in Sarikei District, Sarawak. International Journal of Advanced Research and Development, 1(3), 17-21.

Maharani, H. R. (2014). Creative thinking in mathematics: Are we able to solve mathematical problems in a variety of way?. International Conference on Mathematics, Science, and Education 2014 (ICMSE 2014), 120-125. 
Malewska, K. (2018). The profile of an intuitive decision maker and the use of intuition in decision-making practice. Management, 22(1), 31-44.

Noor, F. (2018). Pengelolaan sumber daya alam berdasar prinsip fiqh al-bi'ah. Jurnal Ilmiah Pendidikan Pancasila dan Kewarganegaraan, 3(1), 47-55.

Nurhanurawati, Purwanto, As'ari, A. R., \& Irawan, E. B. (2018). Tortuous thinking intuitively in solving problem of sequence convergence. Journal of Physics: Conference Series, $1028(2), 1-6$.

Okoli, J., \& Watt, J. (2018). Crisis decision-making: The overlap between intuitive and analytical strategies. Management Decision, 56(5), 1122-1134.

Panbanlame, K., Sangaroon, K., \& Inprasitha, M. (2014). Students' intuition in mathematics class using lesson study and open approach. Psychology, 05(13), 1503-1516.

Pavani, P., \& Rajeswari, T. R. (2014). Impact of plastics on environmental pollution. Journal of Chemical and Pharmaceutical Sciences, (3), 87-93.

Purwanti, D., \& Musadat, A. A. (2018). Increasing students' achievement on simple twodimensional figure materials through students STAD for third graders of school. International Journal of Multicultural and Multireligious Understanding, 5(5), 80-86.

Rahayu, T., Syafril, S., Wati, W., \& Yuberti, Y. (2017). The application of STAD- cooperative learning in developing integrated science on students worksheet. Jurnal Ilmiah Pendidikan Fisika Al-Biruni, 6(2), 247-254.

Sari, I. F. (2017). Pemberian reward dan punishment dengan kombinasi model pembelajaran kooperatif tipe STAD untuk meningkatkan motivasi dan hasil belajar peserta didik kelas $\mathrm{X}$ pada mata pelajaran ekonomi di SMA negeri 1 Mlati. Jurnal Pendidikan dan Ekonomi, $6(1), 1-8$.

Sulaeman, D., Arif, S., \& Sudarmadji. (2018). Trash-polluted irrigation: Characteristics on agriculture. IOP Conference Series: Earth and Environmental Science, 148, 1-12.

Sutiarso, S., Coesamin, C., \& Nurhanurawati, N. (2017). The effect of various media scaffolding on increasing understanding of students' geometry concepts. Journal on Mathematics Education, 9(1), 95-102.

Valderrama-Hernández, R., Alcántara, L., \& Limón, D. (2017). The complexity of environmental education: Teaching ideas and strategies from teachers. Procedia - Social and Behavioral Sciences, 237, 968-974.

Vale, I., \& Barbosa, A. (2018). Mathematical problems: The advantages of visual strategies. Journal of the European Teacher Education Network, 13, 23-33.

Wood, D., Bruner, J. S., \& Ross, G. (1976). The role of tutoring in problem solving. Journal of Child Psychology and Psychiatry, 17(2), 89-100.

Zuhdi, M. H. (2015). Paradigma fiqh al-bi'ah berbasis kecerdasan naturalis: Tawaran hukum islam terhadap krisis ekologi. Al-'Adalah, 12(2), 771-784. 